\title{
Pengejawantahan blended learning untuk mendukung kultur lingkungan belajar berbasis kehidupan pasca pandemi
}

\author{
Zahid Zufar At Thaariq \\ Fakultas Ilmu Pendidikan, Universitas Negeri Malang \\ Malang, Indonesia \\ zahid.thoriq.1701216@students.um.ac.id \\ Rista Anggraini \\ Fakultas Ilmu Sosial, Universitas Negeri Malang \\ Malang, Indonesia \\ ristaa765@gmail.com
}

\begin{abstract}
This paper aims to provide a description related to the application of blended learning in a life-based learning environment in the post-pandemic period. Online learning, whether consciously or not, has made teacher skills in developing learning slowly increase. This causes a change in a new learning culture that begins to enter the orientation to life. This change is also strengthened by the existence of a policy plan to implement face-to-face learning. Therefore, the author is interested in examining blended learning which is likely to occur as an answer in supporting a new learning culture after the pandemic. This study is "embodiment" which means the author tries to provide an opinion on the realization of the blended learning process with an orientation to life-based learning as an alternative solution for teachers in developing learning later. It is hoped that this paper will be able to provide insights that have been accumulated with various existing researches, so that it can be used as an alternative reference for further research
\end{abstract}

Keywords: blended learning; life-based learning; post-pandemic

\begin{abstract}
Abstrak
Penulisan ini bertujuan untuk memberikan penjabaran terkait dengan penerapan blended learning dalam lingkungan belajar berbasis kehidupan pada masa pasca pandemi. Pembelajaran secara daring baik disadari maupun tidak, telah menjadikan keterampilan guru dalam mengembangkan pembelajaran dapat meningkat secara perlahan. Hal ini menyebabkan terdapat perubahan kultur belajar baru yang mulai memasuki pada orientasi pada kehidupan. Perubahan ini juga terkuatkan dengan adanya rencana kebijakan untuk melaksanakan pembelajaran secara tatap muka. Maka dari itu, penulis tertarik untuk menelaah blended learning yang kemungkinan akan terjadi sebagai jawaban dalam mendukung kultur belajar baru pasca pandemi. Telaah ini bersifat "pengejawantahan" yang berarti penulis berusaha memberikan pendapat mengenai perwujudan proses blended learning dengan orientasi pada belajar berbasis kehidupan sebagai solusi alternatif bagi guru dalam mengembangkan pembelajaran nantinya. Harapannya tulisan ini mampu memberikan pandangan yang terakumulasi dengan berbagai riset yang ada, sehingga dapat dijadikan referensi alternatif bagi penelitian selanjutnya
\end{abstract}

Kata Kunci: blended learning; belajar berbasis kehidupan; pasca pandemi 


\section{PENDAHULUAN}

Pandemi COVID-19 telah memberikan berbagai dampak di dalamnya. Hingga saat ini, terhitung pada 5 Juni 2021, jumlah yang terkonfirmasi positif sebanyak 1.850.206 orang dengan jumlah 1.701 .784 orang sembuh dan 51.449 orang meninggal dunia (Website Resmi Penanganan COVID-19, 2021). Dampak yang diberikan dari adanya pandemi ini adalah perubahan dari "nyata" menjadi "maya". Sebagaimana yang dapat dicontohkan seperti berbelanja, berinteraksi maupun dalam konteks belajar mengajar.

Pandemi Covid-19 memaksa dunia pendidikan untuk bertransformasi. Hal ini dikarenakan untuk wilayah zona hijau dan kuning sudah dapat melaksanakan pembelajaran tatap muka dengan syarat dan ketentuan yang berlaku. Sedangkan untuk daerah yang berada pada zona jingga dan merah wajib dilaksanakan pembelajaran non tatap muka (Kemendikbud, 2020). Maka hal ini menjadikan diberlakukannya pembelajaran daring bagi wilayah yang terdampak pada zona jingga dan merah.

Pembelajaran daring dapat diterapkan pada beragam mata pelajaran. Mata pelajaran seperti pelatihan teknis dan keterampilan berpikir urutan lebih rendah (seperti menghafal) "meminjamkan" diri mereka paling mudah ke pembelajaran daring (Carliner, 2004). Hal ini berarti pembelajaran daring memberikan fleksibilitas baik tempat maupun waktu dalam konteks belajar mengajar. Pandemi COVID-19 memberikan dampak perubahan pembelajaran dengan optimalisasi proses blended learning atau full online dalam pelaksanaan pendidikan di setiap jenjang (Thaariq, 2020).

Peraturan baru dikeluarkan oleh Kemendikbud yang menekankan dilaksanakannya kembali pembelajaran secara tatap muka. Hal ini sebagaimana pernyataan dari Mendikbud Nadiem Makarim yang dilansir dari detik.com yang menyatakan akan diberlakukannya Pembelajaran Tatap Muka Terbatas (PTMT). Hal ini berarti, implementasi pembelajaran tatap muka nantinya akan dilakukan secara terbatas. Sebagaimana yang terlampir dalam laman detik.com, aturan tersebut memuat mulai dari jaga jarak hingga penataan lingkungan kelas. Pembelajaran tatap muka masih akan terus berkombinasi dengan Pembelajaran Jarak Jauh (PJJ) (Kemendikbud, 2021). Hal ini berarti, aturan ini akan berpotensi dalam mewujudkan blended learning dalam penerapannya.

Istilah blended learning sering digunakan di antara para peneliti dan praktisi. Blended learning ini berasal dari dua kata yaitu "blend" dan "learning". Kata "blended" berarti menggabungkan hal-hal dan belajar menunjukkan asimilasi pengetahuan baru (Simarmata et al., 2018). Meskipun istilah ini sering digunakan, ada ambiguitas tentang apa yang sebenarnya dimaksud. Dalam tinjauan kritisnya, Oliver dan Trigwell menyimpulkan bahwa istilah blended learning hanya membutuhkan dua atau lebih hal yang berbeda yang kemudian dapat dicampur (Hrastinski, 2019). Hal ini dikarenakan dengan adanya padatnya mobilitas manusia melahirkan teknologi-teknologi baru, dimanamenjadi penyebab adanya model pembelajaran blanded learning untuk menjawab inovasi di tengah tantangan zaman (Purnomo et al., 2017).

Hal ini juga diperkuat dengan preferensi pebelajar sekarang yang cenderung bebas dalam mengakses sumber belajar (Thaariq et al., 2020). Kebebasan ini juga memicu suatu konsep belajar berbasis kehidupan. Adapun akhir dari adanya kegiatan tujuan pembelajaran yaitu tidak 


\section{Pengejawantahan Blended Learning untuk Mendukung Kultur Lingkungan Belajar Berbasis Kehidupan Pasca Pandemi}

ada batasan yang digunakan dalam dunia pendidikan yang berorientasi pada jenis pekerjaan saja, menyebabkan belajar formal seringkali dianggap memiliki batasan waktu (Praherdhiono et al., 2018). Life based learning menyatakan bahwa kenyamanan dalam lingkungan belajar dalam kehidupan menjadi sumber belajar (Michel \& Durdella, 2019).

Selama pelaksanaan pembelajaran daring di masa pandemi COVID-19, terdapat beberapa kendala yang dialami oleh guru-guru dalam pelaksanaannya. Salah satunya adalah adanya bentuk penugasan secara daring. Adanya bentuk tugas berbasis daring ini sebenarnya dianggap sebagai beban bagi sebagian siswa dan orang tua. Bagi siswa dan orang tua yang belum pernah mengenal gawai akan bingung dan akhirnya tidak menyelesaikan tugas yang diberikan oleh guru (Syarifudin, 2020). Hal ini berdampak pada kesiapan guru dalam pembelajaran daring yang dilakukan. Sebagai contoh penelitian yang dilakukan oleh Ayuni et al (2020) menunjukkan bahwa guru pada jenjang TK masih belum siap dalam menghadapi pembelajaran daring dikarenakan beberapa faktor seperti fasilitas yang kurang memadai dan adanya persepsi dari orang tua yang mengatakan pembelajaran daring itu sukar dilakukan. Hal ini mengakibatkan kurang maksimalnya keterlibatan siswa selama pembelajaran daring, dibuktikan dengan penelitian yang dilakukan oleh Anugrahana (2020) menyatakan bahwa hanya 50\% siswa yang aktif terlibat secara penuh, $33 \%$ siswa yang terlibat aktif. Sedangkan $17 \%$ lainnya, siswa yang kurang aktif dan kurang berpartisipasi dalam pembelajaran daring. Penting untuk diperhatikan bahwa sebenarnya guru juga dapat mengajarkan dengan berbagai sumber yang digunakan. Guru-guru juga bekerja dari rumah dengan berkoordinasi dengan orang tua, bisa melalui video call maupun foto kegiatan belajar anak dirumah untuk memastikan adanya interaksi antara guru dengan orang tua (Dewi, 2020)

Maka dari itu sebagai upaya dalam memecahkan masalah tersebut, penulis tertarik untuk menelaah terkait dengan pengejewantahan blended learning dalam mendukung lingkungan belajar berbasis kehidupan pada pasca pandemi. Kata "pengejewantahan" diambil dari sisi bahasa yang berarti (1) penjelmaan (perwujudan, pelaksanaan, manifestasi) suatu posisi, kondisi, sikap, pendirian, dan sebagainya dan (2) proses, cara, perbuatan mengejawantahkan, penjelmaan, perwujudan serta manifestasi (Kamus Besar Bahasa Indonesia, 2021). Oleh karena itu, diharapkan dengan adanya judul ini dapat memberikan upaya perwujudan blended learning yang dapat mendukung lingkungan belajar berbasis kehidupan pada masa pasca pandemi nantinya.

\section{METODE}

Metode penelitian kualitatif ini menggunakan tinjauan secara naratif (narrative review). Sebuah tinjauan naratif literatur pada artikel peer review dalam lingkup studi diadopsi sebagai metode penelitian. Kriteria untuk yang dipilih dalam artikel yang ditinjau dengan kriteria khusus di dalamnya (Uwajeh \& Ezennia, 2018). Pencarian dilakukan pada database google scholar, artikel yang direview dalam bahasa Inggris, artikel terbit pada jurnal, artikel hasil penelitian dan topik tentang blended learning dan life-based learning. Langkah-langkah dalam melakukan tinjauan ini adalah (1) mencari pokok kondisi yang ada, (2) merancang pokok 


\section{Zahid Zufar At Thaariq, Rista Anggraini}

gagasan yang diberikan, (3) mencari literatur yang diperlukan dan (4) menarik suatu kesimpulan

\section{HASIL DAN PEMBAHASAN}

Perubahan diidentikkan dengan proses perpindahan menuju hal yang berbeda, baik dalam ranah positif atau negatif. Perubahan akan terus terjadi seiring berkembangnya kemajuan zaman, salah satunya yaitu perubahan sosial budaya. Terjadinya perubahan sosial budaya mendorong beragam jenis faktor baik dari dalam maupun luar masyarakat (Hernawan, 2012). Beberapa faktor yang mempengaruhi timbulnya perubahan yaitu (1) kontak dengan budaya lain, (2) majunya sistem pendidikan formal, (3) sikap saling menghargai dan memiliki kemauan untuk berkembang, (4) saling menghargai perbuatan yang menyimpang (deviation) yang bukan merupakan delik, (5) open stratification atau sistem terbuka lapisan masyarakat, (6) penduduk yang heterogen, (7) ketidakpuasan dalam bidang kehidupan tertentu, (8) orientasi ke masa depan, (9) nilai yang menyatakan bahwa manusia harus senantiasa berikhtiar dalam upaya memperbaiki hidupnya (Ningsih 2017). Perubahan sosial budaya yang terjadi dalam kehidupan masyarakat akan terjadi dengan berbagai proses mulai dari lambat, cepat atau berkesinambungan (Hatuwe et al., 2021).

Upaya dalam menghadapi perubahan sosial budaya perlu adanya pendidikan yang mengiringinya dari setiap perkembangan zaman (Yuristia, 2017). Hal ini dikarenakan pendidikan mampu melakukan perubahan pada sosial budaya, yaitu mengemban ilmu pengetahuan, penyesuaian nilai-nilai, serta perilaku yang mendorong adanya pembangunan dan penguasaan beragam bidang keterampilan dalam menggunakan teknologi sebagai upaya mempercepat pembangunan, yang bertujuan untuk menciptakan kesejahteraan dan kemakmuran suatu bangsa. Pembangunan merupakan impian bagi setiap Negara di dunia dalam memajukan bangsanya (Simanjuntak, 2017). Oleh karena itu pendidikan memegang peran penting dalam memajukan bangsa. Hadirnya pendidikan mampu mencerdaskan kehidupan bangsa, bagaimanapun kondisi dalam suatu Negara pendidikan harus tetap terlaksana, seperti halnya pada masa pandemi COVID-19. Di mana pada masa ini semua kegiatan dibatasi, akibatnya kegiatan pembelajaran dilakukan secara online atau online learning.

Pembelajaran online diartikan menjadi suatu pengalaman belajar dalam lingkup sinkronus atau asinkron menggunakan perangkat yang bisa terhubung dengan internet seperti laptop, komputer, handphone dan lain sebagainya (Dhawan, 2020). Lingkungan sinkron adalah lingkungan belajar yang terstruktur, di mana pebelajar menghadiri kelas secara langsung, ada waktu nyata, interaksi antara pendidik dan peserta didik serta ada umpan balik yang dilakukan melalui media maya. Sedangkan lingkungan belajar asinkron merupakan lingkungan belajar yang tidak terstruktur dengan baik, di mana bahan pembelajaran tidak tersedia secara langsung, hanya terdapat pada sistem pembelajaran dan forum, serta umpan balik dan tanggapan tidak dilakukan secara langsung (Littlefield \& Gjertsen, 2018). Online learning memunculkan berbgai pandangan yang diutarakan masyarakat. Seperti hasil penelitian yang dilakukan oleh Firman \& Rahayu (2020) yang mengemukakan bahwa, pembelajaran online merupakan 


\section{Pengejawantahan Blended Learning untuk Mendukung Kultur Lingkungan Belajar Berbasis Kehidupan Pasca Pandemi}

pembelajaran yang menyenangkan dan nyaman, hal ini dikarenakan mahasiswa lebih nyaman untuk bertanya serta mengemukakan pendapat dalam forum perkuliahan yang dilakukan secara online. Prawiyogi (2020) juga mengemukakan hal yang sama bahwa, pembelajaran online efektif digunakan siswa selama pembelajaran jarak jauh. Akan tetapi pembelajaran online juga mendapat pandangan yang negatif berdasarkan beberapa hasil penelitian. Seperti hasil penelitian yang dikemukakan oleh Ameli (2020) pembelajaran online (daring) kurang efektif karena kurangnya sarana dan prasarana serta ketidaksiapan edukasi teknologi. Fauziyah (2020) juga mengemukakan hal yang sama bahwa pembelajaran online terdapat banyak hambatan mulai dari jaringan yang kurang stabil, sarana dan prasarana yang kurang memadai, guru dan dosen yang kurang menguasai penggunaan teknologi atau sosial media yang digunakan untuk media pembelajaran.

Berbagai pandangan yang diutarakan masyarakat merupakan hal yang benar, karena sejatinya setiap kebijakan terdapat kekurangan dan kelebihan. Masyarakat bebas mengutarakan pendapatnya sesuai apa yang dia alami. Kebebasan berpendapat juga terdapat dalam Undangundang pasal 1 ayat 1 No. 9 Tahun 1998 yang berbunyi Kemerdekaan Menyampaikan Pendapat di Muka Umum yang menjelaskan bahwa setiap warga negara berhak untuk menyampaikan pikiran dengan lisan, tulisan, dan sebagainya secara bebas dan bertanggung jawab sesuai dengan ketentuan peraturan perundang-undangan yang berlaku. Undang-undang Dasar 1945 pasal 28 I ayat 4 juga mengemukakan bahwa perlindungan, pemajuan, penegakan, dan pemenuhan hak asasi manusia adalah tanggung jawab negara, terutama pemerintah. Sehingga dalam hal ini orang diperbolehkan bebas menyatakan pendapatnya, akan tetapi juga perlu pengendalian dalam mengutarakan pendapat tersebut supaya tidak menimbulkan permasalahan yang berkepanjangan antar anggota masyarakat (Susanto, 2019).

Berbagai kebijakan ini dilakukan oleh pemerintah untuk menciptakan ketertiban dalam masyarakat, terutama dalam pendidikan. Pendidikan yang mencerdaskan rakyat merupakan pendidikan yang mampu membawa warga negaranya sebagai anggota masyarakat yang demokratis (Hatuwe et al., 2021). Tujuan dari pendidikan ini adalah supaya siswa bisa merasakan bahwa, sekolah merupakan tempat bagi mereka untuk belajar menggali potensi yang terdapat dalam dirinya.

Faktanya yang sering ditemui, Istilah-istilah yang selalu melekat dalam dunia belajar adalah "belajar harus di dalam kelas". Sebuah konsekuensi yang logis sebagai akibat dari kebijakan yang terlalu menitikberatkan pendidikan formal sebagai aspek pendidikan utama dengan mengesampingkan pendidikan nonformal dan informal (Toenlioe, 2018). Hal ini juga menginisiasi adanya istilah "pasal 1 guru selalu benar, pasal 2 apabila guru salah, maka dikembalikan kepada pasal 1". Tentunya, ini sangat memungkinkan suatu proses pembelajaran yang dipegang kendali secara sepenuhnya oleh guru (teacher-centered learning).

Konsep belajar dan pembelajaran bukan merupakan proses yang pendek, namun akar psikologi dalam bidang pendidikan merupakan "mesin utama" Teknologi Pendidikan di Indonesia. Pada dasarnya dalam perspektif psikologi pendidikan, individu merupakan pemilik hidupnya yang sesungguhnya. Penyesuaian terhadap kepemilikan hidup sangat bergantung dengan individu pebelajar (Praherdhiono, 2019). Kehadiran teknologi telah mempercepat 
segala sesuatu sehingga ide-ide atau gagasan-gagasan telah mengalami perubahan dalam suatu generasi, bukan antar generasi. Teknologi komunikasi dan informasi sebagai sarana untuk memudahkan belajar manusia. Pergeseran paradigma dari mengajar ke belajar sebenarnya telah lama terjadi (Setyosari, 2019). Guru Besar Teknologi Pendidikan dalam pidato pengukuhannya memberikan rincian dalam paradigma belajar yang terjadi dalam tabel berikut (Degeng, 1998).

Tabel 1 Perbedaan paradigma lama dengan paradigma baru (Degeng, 1998)

\begin{tabular}{ll}
\multicolumn{1}{c}{ Behavioristik } & \multicolumn{1}{c}{ Konstruktivistik } \\
\hline $\begin{array}{l}\text { Pengetahuan adalah objektif, memiliki sifat yang pasti dan tetap } \\
\text { serta tidak dapat berubah. Pengetahuan memiliki struktur yang } \\
\text { rapi }\end{array}$ & $\begin{array}{l}\text { Pengetahuan adalah tidak objektif, bersifat temporer, berubah-ubah } \\
\text { dan tidak memiliki kepastian }\end{array}$ \\
$\begin{array}{l}\text { Belajar adalah perolehan pengetahuan, sedangkan mengajar } \\
\text { adalah memindahkan pengetahuan }\end{array}$ & $\begin{array}{l}\text { Belajar adalah pembentukan pengetahuan yang berasal dari } \\
\text { interpretasi. Mengajar adalah menyunsun lingkungan supaya peserta } \\
\text { didik termotivasi dalam menggali makna serta menghargai } \\
\text { ketidakmenentuan }\end{array}$ \\
$\begin{array}{l}\text { Peserta didik diharapkan akan mempunyai pemahaman yang sama } \\
\text { dengan pengetahuan yang dipelajari. Artinya apa yang dipahami } \\
\text { oleh guru itulah yang harus dipahami oleh peserta didik }\end{array}$ & $\begin{array}{l}\text { Peserta didik akan mempunyai kemampuan memahami yang berbeda } \\
\text { terhadap suatu pengetahuan tergantung dari pengalaman dan } \\
\text { perspektif yang dipakai dalam menginterpretasikannya. }\end{array}$ \\
\hline
\end{tabular}

Meskipun tabel di atas merupakan rujukan dua dekade lalu, namun penerapannya sedang "demam" pada dunia pembelajaran saat ini. Hal ini juga dinyatakan dalam pandangan dari Setyosari (2021) yang menyatakan bahwa pembelajaran saat ini telah mengalami "keterlambatan", karena paradigma konstruktivistik, utamanya dalam pembelajaran daring baru dibahas sekarang ini sejak terjadinya pandemi COVID-19. Maka dari itu, dengan mendasarkan pada penjelasan tabel di atas menandakan pada konsep belajar dan pembelajaran yang telah diimplementasikan pada pendidikan dan pembelajaran mengakui perlu adanya difusi dan inovasi (Praherdhiono, 2019). Lebih lanjut, Praherdhiono (2019) menyatakan bahwa kesadaran yang perlu ditanamkan pada diri guru adalah siswa di era informasi, yang didominasi oleh generasi $\mathrm{Z}$ atau Alpha, memiliki akses lebih cepat terhadap teknologi dan konten daripada generasi sebelumnya dan cenderung tidak memiliki batasan. Performa siswa perlu ditingkatkan dengan menambahkan "lensa baru" bagi perancang belajar dan pembelajaran untuk dapat digunakan dalam mengembangkan, menyampaikan, dan memfasilitasi pembelajaran. Maka dari itu, salah satu bentuk dukungannya adalah penerapan blended learning dalam proses belajar mengajar.

Setelah merebaknya pandemi Covid-19, muncul minat baru pada peran dan kegunaan pembelajaran online dan digital pada saat terjadi krisis di seluruh dunia. Eksperimen yang berbeda dengan pembelajaran kolaboratif, pembelajaran konstruktif, pembelajaran kooperatif dan pembelajaran transformatif telah menunjukkan bahwa dengan mengadopsi teknologi yang dapat diakses, fleksibel dan terjangkau dalam pendidikan dan dengan mengintegrasikan secara langsung dan aktivitas online sambil menyusun tujuan pembelajaran dan menilai hasil pembelajaran yang diharapkan dari para pelajar, cara-cara yang lebih baru dan efektif dari pengalaman belajar dapat divisualisasikan (Bordoloi et al., 2021). Salah satu bentukan pembelajarannya adalah blended learning. 


\section{Pengejawantahan Blended Learning untuk Mendukung Kultur Lingkungan Belajar Berbasis Kehidupan Pasca Pandemi}

Blended learning dapat dilihat dari perspektif pembelajaran sinkron dan asinkron. Merupakan upaya untuk menerapkan elemen pembelajaran sinkron seperti interaksi tatap muka dengan instruktur dan kerja kolaboratif dengan teman sebaya sebagai pelengkap kegiatan belajar asynchronous dari individu siswa (Chaeruman et al., 2018). Blended learning dapat diartikan sebagai tanggapan terhadap perkembangan teknologi. Ini tidak hanya dipandang sebagai kombinasi online dengan pembelajaran tatap muka. Thorne mendefinisikan pembelajaran campuran sebagai peluang untuk mengintegrasikan kemajuan inovasi teknologi yang dapat ditawarkan secara online dan tatap muka (Thorne, 2003). Sebagai respon terhadap perkembangan teknologi, blended learning pada dasarnya merupakan kombinasi dari pembelajaran tatap muka terbaik dengan pembelajaran online terbaik (Watson, 2008). Artinya, blended learning bersifat dinamis merespon perkembangan teknologi dan kebutuhan pembelajaran itu sendiri. Konsekuensinya, integrasi teknologi (paduan teknologi) dalam blended learning akan bergantung pada konteks. Konteks yang berbeda memiliki karakteristik dan kebutuhan yang berbeda. Konsekuensinya, diperlukan paduan blended learning yang berbeda (Chaeruman \& Maudiarti, 2018).

Blended learning merupakan sarana yang memungkinkan untuk memberikan kemudahan siswa dalam peningkatan fleksibilitas, aksesibilitas, dan kedalaman pembelajaran yang ditawarkan oleh dunia internet (Dziuban et al., 2018). Kontinum blended learning terdiri dari kategori berikut: 1) Kurikulum online penuh dengan semua pembelajaran dilakukan secara online dan dari jarak jauh dan tidak ada komponen tatap muka, 2) Kurikulum sepenuhnya online dengan pilihan untuk pengajaran tatap muka, tetapi tidak diharuskan ,3) Sebagian besar atau sepenuhnya kurikulum online dengan hari-hari tertentu yang diperlukan di ruang kelas atau lab komputer, 4) Sebagian besar atau sepenuhnya kurikulum online di lab komputer atau ruang kelas tempat siswa bertemu setiap hari, 5) Pengajaran di kelas dengan komponen online yang penting dan diperlukan yang memperluas pembelajaran di luar di kelas dan di luar hari sekolah, 6) Pengajaran di kelas yang mengintegrasikan sumber daya online, tetapi terbatas atau tidak ada persyaratan bagi siswa untuk online, 7) Pengaturan tatap muka tradisional dengan sedikit atau tanpa sumber daya atau komunikasi online (Hrastinski, 2019). Hal ini semakin membuka jalan "emas" dari kebijakan merdeka belajar yang saat ini telah diterapkan.

Merdeka belajar diartikan sebagai kebebasan dalam belajar, yaitu memberikan peluang kepada siswa untuk belajar dengan bebas dan tenang, rileks dan bahagia tanpa adanya kesulitan dan tekanan dengan memperhatikan bakat alaminya, tanpa memaksa mereka untuk belajar atau menguasai bidang ilmunya di luar hobi dan kemampuannya, sehingga masing-masing memiliki portofolio yang sesuai dengan passion masing-masing. Sebab, memberikan beban kepada siswa di luar kemampuannya merupakan perbuatan yang tercela dalam akal sehat dan tidak mungkin dilakukan oleh guru yang bijak. Ini seperti siswa tunanetra dan guru memintanya untuk memberi tahu apa dan bagaimana matahari kepada teman-temannya (Abidah et al., 2020).

Konsep merdeka belajar yang dikemukakan Nadiem Makariem adalah kebebasan berpikir. Guru menjadi pokok utama dalam pendidikan memiliki kebebasan untuk menerjemahkan kurikulum secara mandiri sebelum diajarkan kepada siswa, dengan guru diharapkan bisa 
memahami kurikulum yang telah ditentukan oleh karena itu guru akan menjawab kebutuhan siswa selama berlangsungnya kegiatan pembelajaran. Adanya hal ini diharapkan pengembangan program pendidikan pembelajaran mandiri mampu mengembangkan kompetensi guru dalam pembelajaran. Pembelajaran yang menarik, menyenangkan, dan bermakna, sehingga pencapaian tujuan pendidikan dari sisi guru sebagai pendidik dan siswa sebagai pendidik dapat terwujud. Kebebasan dalam pembelajaran meliputi kondisi kemandirian dalam mencapai tujuan, metode, materi, dan evaluasi pembelajaran, baik bagi guru maupun siswa (Izza et al., 2020).

Adanya teknologi komputer dan jaringan di Indonesia dapat mempengaruhi proses kegiatan pembelajaran di kelas. Munculnya teknologi ini, pembelajaran dapat dilakukan di mana saja. Jika sebelum teknologi komputer dan jaringan digunakan di Indonesia, masyarakat mengirimkan modul pembelajaran dalam bentuk belajar mandiri, maka optimalisasi komputer dan internet dalam pembelajaran dapat mempermudah pendistribusian modul menggunakan email atau dapat diunduh pada website tertentu yang telah disediakan (Ramadania \& Aswadi, 2020). Hal ini berdampak pada adanya potensi diterapkannya tatanan lingkungan belajar berbasis kehidupan.

Life Based Learning (Belajar berbasis Kehidupan) adalah proses memperoleh pengetahuan dan keterampilan untuk memahami hakikat kehidupan, terampil memecahkan masalah kehidupan, menjalani kehidupan yang seimbang dan harmonis. Life Based Learning menyajikan konsep bahwa belajar dari kehidupan adalah pembelajaran yang nyata. Sekolah sejati bagi manusia adalah kehidupan atau pengalaman hidup mereka sendiri (Hidayat et al., 2019). Pembelajaran berbasis kehidupan mengusulkan bahwa belajar untuk bekerja tidak terbatas pada belajar di tempat kerja. Premis yang mendasari pembelajaran berbasis kehidupan adalah bahwa semua pembelajaran saling berkaitan, sehingga tidak mudah untuk memisahkan pembelajaran di tempat kerja dari jenis pembelajaran lainnya (Staron, 2011). Menurut penelitian dari Kastur (2020) menunjukkan model pembelajaran berbasis kehidupan adalah kunci untuk mengubah dan mengembangkan pembelajaran ekologi baru dalam kursus tata rias. Model pembelajaran berbasis kehidupan dapat digunakan sebagai umpan balik untuk melaksanakan mata kuliah tata rias yang semakin kontekstual-integratif-holistik. Pembelajaran ini juga dapat meningkatkan keterampilan siswa dalam mencari pekerjaan. Hal ini baik secara teoritis maupun praktik, pembelajaran berbasis kehidupan mampu mengorganisasi potensi yang ada pada manusia.

Sejak diberlakukannya pembelajaran daring, semua pelaku pendidikan terus melakukan berbagai macam cara agar proses pembelajaran yang dilakukan tetap dapat optimal. Pembelajaran daring merupakan pembelajaran yang dialakukan dalam konteks ruang dan waktu (synchronicity). Kegiatan pembelajaran daring memiliki dua jenis, yaitu pembelajaran serentak (synchronous learning) dan pembelajaran tidak serentak (asynchronous learning) (Miller, 2014). Proses pembelajaran dapat dilihat dari sisi waktu dimana kegiatan pembelajaran dapat terjadi dalam dua situasi dan kondisi, yaitu serentak dan tidak serentak. Hal ini dapat dikatakan bahwa, kegiatan pembelajaran dapat berlangsung antara yang belajar dan membelajarkan berada dalam waktu yang sama dan sebaliknya. Chaeruman (2020) 


\section{Pengejawantahan Blended Learning untuk Mendukung Kultur Lingkungan Belajar Berbasis Kehidupan Pasca Pandemi}

mengelompokkan setting belajar serentak ke dalam dua kategori, yaitu pembelajaran yang terjadi pada ruang dan waktu yang sama (live-synchronous learning) atau dikenal dengan tatap muka dan pembelajaran yang terjadi pada waktu yang sama, tetapi di ruang yang berbeda satu sama lain (virtual-synchronous learning). Begitupun untuk pembelajaran tidak serentak, dikelompokkan menjadi pembelajaran yang terjadi kapan saja dan di mana saja tanpa orang lain (self-directed asynchronous learning) dan pembelajaran yang terjadi kapan saja dan dimana saja bersama dengan orang lain (collaborative asynchronous learning) (Chaeruman, 2020). Berikut ini merupakan seting ruang belajar dengan blended learning (Chaeruman, 2017)

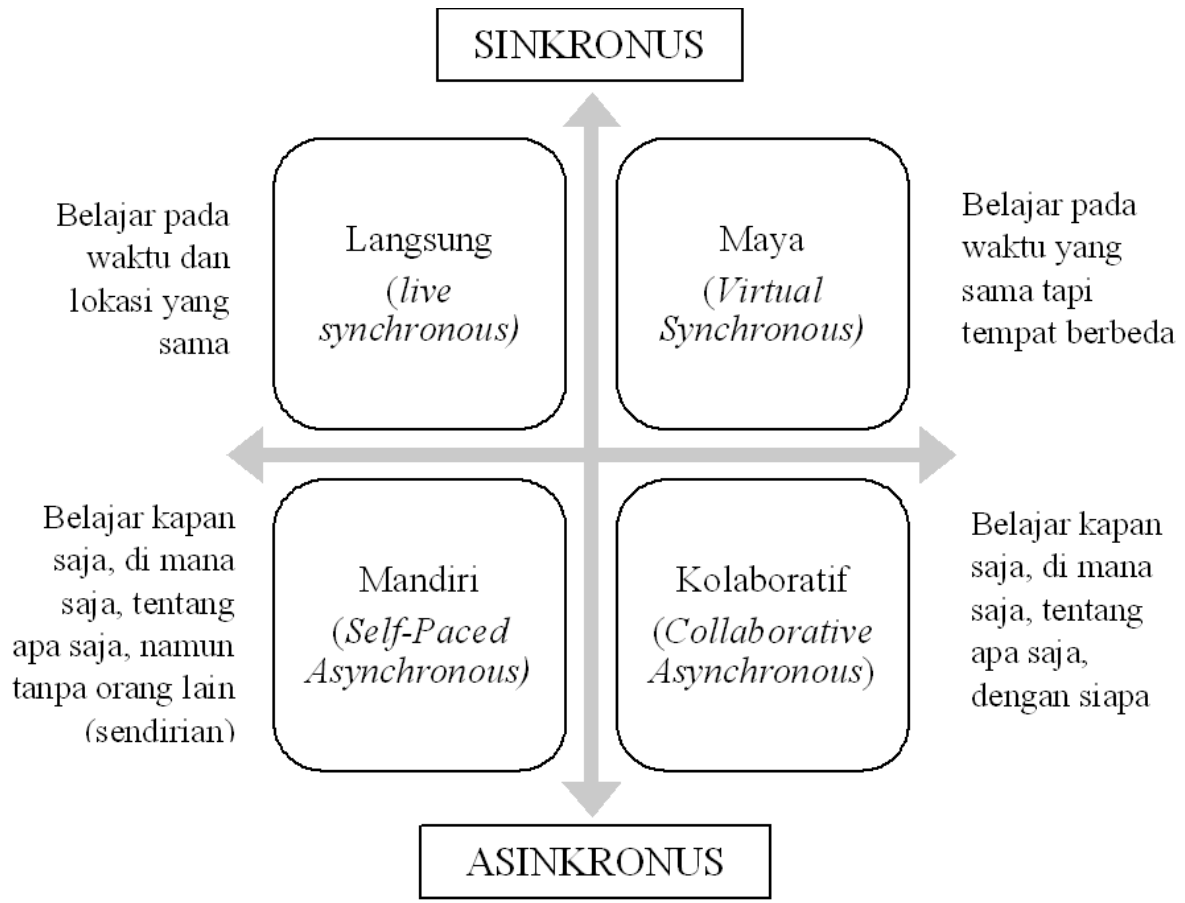

Gambar 1 Ruang Belajar (Chaeruman, 2017)

Maka, bagaimana solusi menerapkan lingkungan belajar berbasis kehidupan dengan mode seting blended learning? Seting blended learning dengan lingkungan belajar berbasis kehidupan berdasarkan pada asumsi dari penulis adalah sebagaimana penjabaran dari tabel berikut (diadaptasi dari Chaeruman, 2017).

Tabel 2 Aktivitas Lingkungan Belajar Berbasis Kehidupan dengan seting Blended Learning (Chaeruman, 2017)

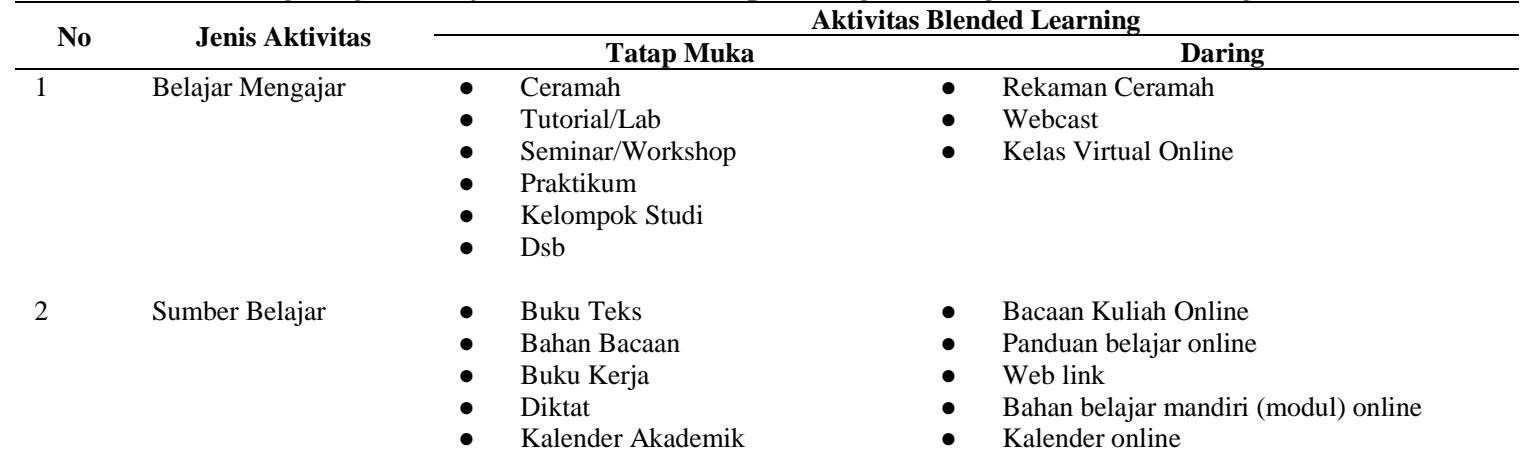




\begin{tabular}{|c|c|c|c|}
\hline \multirow{2}{*}{ No } & \multirow{2}{*}{ Jenis Aktivitas } & \multicolumn{2}{|c|}{ Aktivitas Blended Learning } \\
\hline & & Tatap Muka & Daring \\
\hline & & - $\quad$ Dsb & - $\mathrm{dsb}$ \\
\hline 3 & $\begin{array}{l}\text { Komunikasi } \\
\text { Pembelajaran }\end{array}$ & $\begin{array}{ll}\text { - } & \text { Pengumuman sekolah } \\
\text { - } & \text { Pengumuman kelas } \\
\text { - } & \text { Surat formal } \\
\quad \text { Komunikasi guru-siswa }\end{array}$ & $\begin{array}{ll}- & \text { Pengumuman online } \\
- & \text { Email } \\
\text { - } & \text { Forum Diskusi Online } \\
\text { - } & \text { Percakapan online (chat) }\end{array}$ \\
\hline 4 & Aktivitas Individu & $\begin{array}{ll}- & \text { Membuat tulisan } \\
-\quad & \text { Melakukan eksperimen } \\
\text { - } & \text { Membaca } \\
\text { Tanya jawab }\end{array}$ & $\begin{array}{ll}\text { - } & \text { Jurnal online (blog, wiki, dll) } \\
\text { - } & \text { E-Portfolio } \\
& \text { Latihan dan praktik online }\end{array}$ \\
\hline 5 & Kolaborasi & $\begin{array}{ll}- & \text { Kerja kelompok } \\
\bullet & \text { Diskusi } \\
- & \text { Debat } \\
- & \text { Role Play } \\
\bullet & \text { Proyek }\end{array}$ & 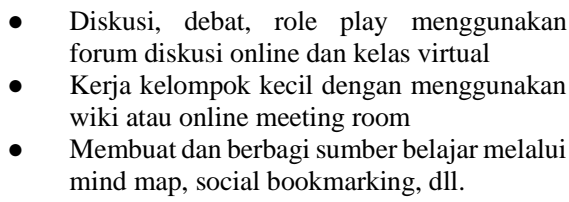 \\
\hline 6 & Asesmen & $\begin{array}{ll}- & \text { Ujian } \\
- & \text { Proyek } \\
- & \text { Unjuk kerja teramati } \\
: \quad \text { Essay } \\
-\quad \text { Oral test } \\
& \text { Pengembangan produk } \\
\end{array}$ & $\begin{array}{ll}- & \text { Ujian online } \\
-\quad & \text { Penugasan online } \\
& \text { Karya yang dikumpulkan melalui wiki, blog } \\
& \text { atau media lainnya }\end{array}$ \\
\hline
\end{tabular}

Maka dari itu, contoh langkah konkret dalam mewujudkan blended learning dengan belajar berbasis kehidupan yang dapat dilakukan oleh guru sangat beragam. Misalnya pada jenjang SD yang memiliki karakteristik "bermain", maka pembelajaran dapat didesain yang menyesuaikan dengan karakteristiknya. Contohnya pada (1) proses belajar mengajar tatap muka dapat menggunakan eksperimen secara sederhana, sehingga tidak selalu menggunakan ceramah sedangkan pada proses daring dapat menggunakan kelas virtual, (2) sumber belajar tatap muka dapat menggunakan lingkungan sekitar untuk menambah wawasan pengalaman belajarnya, sedangkan pada proses daring dapat mengembangkan media pembelajaran yang dapat menambah pengalamannya (dapat berupa augmented reality, buku ajar hypercontent, dan sebagainya), (3) pada komunikasi pembelajaran secara tatap muka, dapat mengandalkan komunikasi langsung antara guru dan siswa, sedangkan pada proses daring dapat mengandalkan forum diskusi online, (4) pada aktivitas individu dalam mode tatap muka dapat dilakukan suatu kegiatan eksperimen atau percobaan, sedangkan pada kegiatan daring dapat dilakukan latihan dan praktik online, (5) pada kegiatan kolaborasi secara tatap muka dapat dilakukan dengan kerja kelompok, sedangkan pada kegiatan daring dapat dilakukan dengan online meeting room dan (6) pada kegiatan asesmen secara tatap muka dapat dilakukan dengan unjuk kerja teramati, sedangkan pada kegiatan asesmen secara daring dapat dilakukan dengan penugasan secara daring. Hal ini juga berlaku pada jenjang lainnya dengan menyesuaikan perkembangan peserta didik pada setiap jenjangnya.

Keseluruhan rangkaian yang dijabarkan dalam tabel di atas menggambarkan bahwa mendayagunakan berbagai sumber-sumber untuk digunakan dalam pembelajaran merupakan proses upaya dalam menata lingkungan belajar berbasis kehidupan. Sebuah indikasi bahwa dengan diterapkannya model ini dapat menjadikan siswa semakin memiliki otonomi tersendiri 


\section{Pengejawantahan Blended Learning untuk Mendukung Kultur Lingkungan Belajar Berbasis Kehidupan Pasca Pandemi}

dalam belajar. Tugas kita sebagai guru adalah mengawal keberhasilan pembelajaran pada era pasca pandemi nantinya yang akan segera banyak mengalami perubahan.

\section{SIMPULAN}

Blended learning merupakan pembelajaran yang berorientasi pada seting lingkungan synchronous maupun asynchronous yang saling terintegrasi satu sama lain. Pembelajaran ini akan berpotensi terimplementasi pada masa pasca pandemi nantinya, di mana segala pembelajaran tatap mukanya bersifat terbatas. Di samping itu, aturan ini juga semakin menguatkan untuk perlu adanya seting lingkungan belajar berbasis kehidupan yang didukung dari proses blended learning. Pengejawantahan yang dapat dilakukan adalah mulai dari (1) aktivitas belajar mengajarnya, (2) sumber belajar yang digunakan, (3) komunikasi pembelajarannya, (4) aktivitas individu, (5) aktivitas kolaborasi dan (6) asesmen yang dilakukan. Keseluruhan rangkaian aktivitas tersebut perlu mengacu pada lingkungan synchronous maupun asynchronous. Karena siswa sudah selayaknya diberikan otonomi seluasluasnya dalam pembelajaran. Untuk itu kajian ini dilakukan dalam rangka membantu guruguru dalam merancang blended learning yang disesuaikan dengan landasan atau pijakan teoritis yang disadurkan berdasarkan riset-riset yang ada. Rekomendasi bagi penelitian selanjutnya adalah dapat mengembangkan konsep atau mode pembelajaran ini sebagai referensi alternatif dalam mengembangkan penelitian dengan topik blended learning, utamanya pada institusi pendidikan formal.

\section{DAFTAR PUSTAKA}

Abidah, A., Hidaayatullaah, H.N., Simamora, R.M., Fehabutar, D. \& Mutakinati, L. 2020. The Impact of Covid-19 to Indonesian Education and Its Relation to the Philosophy of "Merdeka Belajar". Studies in Philosophy of Science and Education. 1(1):38-49.

Ameli, A., Hasanah, U., Rahman, H. \& Putra, A.M. 2020. Analisis keefektifan pembelajaran online di masa pandemi COVID-19. Mahaguru: Jurnal Pendidikan Guru Sekolah Dasar. 2(1):28-37.

Anugrahana, A. 2020. Hambatan, solusi dan harapan: pembelajaran daring selama masa pandemi covid-19 oleh guru sekolah dasar. Scholaria: Jurnal Pendidikan dan Kebudayaan. 10(3):282-289.

Ayuni, D., Marini, T., Fauziddin, M. \& Pahrul, Y. 2020. Kesiapan guru TK menghadapi pembelajaran daring masa pandemi COVID-19. Jurnal Obsesi: Jurnal Pendidikan Anak Usia Dini. 5(1):414-421.

Bordoloi, R., Das, P. \& Das, K. 2021. Perception towards online/blended learning at the time of Covid-19 pandemic: an academic analytics in the Indian context. Asian Association of Open Universities Journal. ahead-of-print(ahead-of-print).

Carliner, S. 2004. An Overview of Online Learning. Human Resource Development.

Chaeruman, U. 2017. Pengembangan Model Desain Sistem Pembelajaran Blended. Universitas Negeri Jakarta. (Doctoral Dissertation). 
Chaeruman, U.A. 2020. Ruang Belajar Baru dan Implikasi terhadap Pembelajaran di Era Tatanan Baru. Kwangsan. 8(1):332450.

Chaeruman, U.A. \& Maudiarti, S. 2018. Quadrant of Blended Learning: a Proposed Conceptual Model for Designing Effective Blended Learning. Jurnal Pembelajaran Inovatif. 1(1):1-5. Chaeruman, U.A., Wibawa, B. \& Syahrial, Z. 2018. Determining the appropriate blend of blended learning: A formative research in the context of Spada-Indonesia. American Journal of Educational Research. 6(3):188-195.

Degeng, I.N.S. 1998. Mencari Paradigma Baru Pemecahan Masalah Belajar dari Keteraturan Menuju Kesemrawutan. Makalah disajikan dalam Pidato Pengukuhan Guru Besar IKIP Malang.

Dewi, W.A.F. 2020. Dampak Covid-19 terhadap implementasi pembelajaran daring di Sekolah Dasar. Edukatif: Jurnal Ilmu Pendidikan. 2(1):55-61.

Dhawan, S. 2020. Online learning: A panacea in the time of COVID-19 crisis. Journal of Educational Technology Systems. 49(1):5-22.

Dziuban, C., Graham, C.R., Moskal, P.D., Norberg, A. \& Sicilia, N. 2018. Blended learning: the new normal and emerging technologies. International Journal of Educational Technology in Higher Education. 15(1):3.

Fauziyah, N. 2020. Dampak Covid-19 Terhadap Efektivitas Pembelajaran Daring Pendidikan Islam. Al-Mau'izhoh. 2(2). http://www.jurnal.unma.ac.id/index.php/am/article/view/2294 Date of access: 07 Jun. 2021.

Firman, F. \& Rahayu, S. 2020. Pembelajaran online di tengah pandemi covid-19. Indonesian Journal of Educational Science (IJES). 2(2):81-89.

Hatuwe, R.S.M., Tuasalamony, K., Susiati, S., Masniati, A. \& Yusuf, S. 2021. Modernisasi terhadap perubahan sosial masyarakat desa namlea kabupaten buru. Nusantara: Jurnal Ilmu Pengetahuan Sosial. 8(1):84-96.

Hernawan, W. 2012. Pengaruh Media Massa Terhadap Perubahan Sosial Budaya Dan Modernisasi Dalam Pembangunan. KOM \& REALITAS SOSIAL. 4(4).

Hidayat, W.N., Patmanthara, S., Sari, R.K. \& Sutikno, T.A. 2019. Cognitive ability improvement in learning resource development course through implementation of lifebased learning models using LMS. In: Vol. 1193. Journal of Physics: Conference Series. IOP Publishing. pp. 012034.

Hrastinski, S. 2019. What Do We Mean by Blended Learning? TechTrends. 63(5):564-569.

Izza, A.Z., Falah, M. \& Susilawati, S. 2020. Studi Literatur: Problematika Evaluasi Pembelajaran dalam Mencapai Tujuan Pendidikan di Era Merdeka Belajar. Konferensi Ilmiah Pendidikan 2020. 1(1):10-15.

Kamus Besar Bahasa Indonesia. 2021. Arti kata ejawantah - Kamus Besar Bahasa Indonesia (KBBI) Online. https://kbbi.web.id/ejawantah Date of access: 06 Jun. 2021.

Kastur, A., Mustaji, M. \& Riyanto, Y. 2020. The Practicality and Effectiveness of Direct Learning Model by Using Life-Based Learning Approach. Studies in Learning and Teaching. 1(3):165-174. 


\section{Pengejawantahan Blended Learning untuk Mendukung Kultur Lingkungan Belajar Berbasis Kehidupan Pasca Pandemi}

Kemendikbud. 2020. https://www.youtube.com/watch?v=0WQJR2-F8eo\&feature=youtu.be Date of access: 19 Sep. 2020.

Kemendikbud. s.a. Pembelajaran Tatap Muka Terbatas Mulai Juli 2021 | Direktorat Jenderal Pendidikan Vokasi. https://vokasi.kemdikbud.go.id/read/pembelajaran-tatap-mukaterbatas-mulai-juli-2021 Date of access: 06 Jun. 2021.

Littlefield, L.M. \& Gjertsen, A.R. 2018. Teaching 21st century brains: Activating working memory in the online world. In: The use of technology in teaching and learning. Washington, DC, US: Society for the Teaching of Psychology. pp. 26-37.

Michel, R. \& Durdella, N. 2019. Exploring Latino/a college students' transition experiences: An ethnography of social preparedness and familial support. Journal of Latinos and Education. 18(1):53-67.

Miller, M.D. 2014. Minds online. Harvard University Press.

Praherdhiono, H. 2019. Konstruksi Belajar Berbasis Kehidupan pada MOOCs. In: Teori dan Implementasi Teknologi Pendidikan: Era Belajar Abad 21 dan Revolusi Industri 4.0. Malang: Seribu Bintang.

Praherdhiono, H., Adi, E.P. \& Prihatmoko, Y. 2018. Konstruksi demokrasi belajar berbasis kehidupan pada implementasi LMS dan MOOC. Edcomtech Jurnal Kajian Teknologi Pendidikan. 3(1):21-28.

Prawiyogi, A.G., Purwanugraha, A., Fakhry, G. \& Firmansyah, M. 2020. Efektivitas Pembelajaran Jarak Jauh Terhadap Pembelajaran Siswa di SDIT Cendekia Purwakarta. Jurnal Pendidikan Dasar. 11(1):94-101.

Purnomo, A., Ratnawati, N. \& Aristin, N.F. 2017. Pengembangan Pembelajaran Blended Learning Pada Generasi Z. Jurnal Teori dan Praksis Pembelajaran IPS. 1(1):70-76.

Ramadania, F. \& Aswadi, D. 2020. Blended Learning dalam Merdeka Belajar Teks Eksposisi. Stilistika: Jurnal Bahasa, Sastra, dan Pengajarannya. 5(1):10-21.

Setyosari, P. 2019. Belajar Abad ke-21 dan Era Revolusi Industri 4.0. In: Teori dan Implementasi Teknologi Pendidikan: Era Belajar Abad 21 dan Revolusi Industri 4.0. Malang: Seribu Bintang.

Setyosari, P. 2021. Isu-Isu Aktual dan Tren Terkini dalam Penelitian Teknologi Pendidikan. Youtube. https://www.youtube.com/watch?v=402g-FRrEZA Date of access: 04 Oct. 2021.

Simanjuntak, F.N. 2017. Pendidikan untuk Pembangunan Berkelanjutan. Jurnal Dinamika Pendidikan. 10(2):169-195.

Simarmata, J., Djohar, A., Purba, J. \& Juanda, E.A. 2018. Design of a Blended Learning Environment Based on Merrill's Principles. Journal of Physics: Conference Series. 954:012005.

Staron, M. 2011. Life-based learning model-a model for strength-based approaches to capability development and implications for personal development planning. Mindful Creations, February. 1-14.

Susanto, M.I. 2019. Kedudukan Hukum People Power dan Relevansinya dengan Hak Kebebasan Berpendapat di Indonesia. Volksgeist: Jurnal Ilmu Hukum dan Konstitusi. 2(2):225-237. 
Syarifudin, A.S. 2020. Impelementasi pembelajaran daring untuk meningkatkan mutu pendidikan sebagai dampak diterapkannya social distancing. Jurnal Pendidikan Bahasa dan Sastra Indonesia Metalingua. 5(1):31-34.

Thaariq, Z.Z.A. 2020. The Use of Social Media as Learning Resources to Support the New Normal. Teknodika. 18(2):80-93.

Thaariq, Z.Z.A., Surahman, E., Murti, S.A., Faqiroh, B.Z. \& Kusworo, N.R. 2020. Analysis of Learners Characteristics and Learning Process Preferences during Online Learning. In: 1st International Conference on Information Technology and Education (ICITE 2020). Atlantis Press. pp. 49-54.

Thorne, K. 2003. Blended learning: how to integrate online \& traditional learning. Kogan Page Publishers.

Toenlioe, A.J.E. 2018. Ilmu dan Filsafat Pendidikan: Kajian Model Dikotomis Sinergis. Malang: Elang Mas.

Uwajeh, P.C. \& Ezennia, I.S. 2018. The Socio-cultural and ecological perspectives on landscape and gardening in Urban Environment: A narrative review. Journal of Contemporary Urban Affairs. 2(2):78-89.

Watson, J. 2008. Blended Learning: The Convergence of Online and Face-to-Face Education. Promising Practices in Online Learning. North American Council for Online Learning.

Website Resmi Penanganan COVID-19. 2021. Beranda. covid19.go.id. https://covid19.go.id/ Date of access: 06 Jun. 2021.

Yuristia, A. 2017. Keterkaitan Pendidikan, Perubahan Sosial Budaya, Modernisasi dan Pembangunan. IJTIMAIYAH Jurnal Ilmu Sosial dan Budaya. 1(1). 